\title{
On the Perfection of Legal System of Environmental Protection in Mining Area
}

\author{
from the Perspective of Humanity
}

\author{
Yu Zhen \\ East China Institute of Technology \\ Fuzhou 344000, Jiangxi, P. R. China \\ yzh6696@hotmail.com
}

\begin{abstract}
The thesis's objecective was to build sound legal system to perfect Mining Area environment with humanity analysis. With its current ecological situation introduction, the thesis analyzed the reason worsing the mining area. The original force of pursuing profit was absolute egoism, and emphasized the stipulation and prevention of the self-serving behavior on the aspect of legal system, in order to punish the misdeed and praise the good deed, and to defend the mineral environment.
\end{abstract}

Keywords- mining area; ecologic environment; humanity; egoism; legal system; perfection

\section{INTRODUCTION}

There are more and more natural disaster appeared recently, such as earthquakes, mud-rock flow, tsunami and thunderstorm etc, which has disturbed human's living environment deeply. Therefore, many researchers have begun to study how to control destroyed behavior to environment and restore the ecological system, however, research on mining area ecological environment is included also. Those researchers offered their opinions from their own obstacle, such as External Theory, State Intervention Theory, Consistent Development Theory, etc. However, those theories are lake of essential acknowledgement to it so that they could not help to solve it.

Researches on law should be built on the bases of humanity and human's behavior. The thesis just explained from humanity; further expounded how to improve law regulation on it. It would be an innovation to explain in this special way.

\section{THE CURRENT ECOLOGICAL SituAtion OF MinING AREA}

With the continuous development of market economy, the fundamental aim "pursuing the maximum profits" has been exaggerated. Mining enterprises followed its absolutely in minimizing costs with backward mining technology and less-utilization of resource. This kind of destructive exploitation, which has kept high cost, high emission in long time has destroyed the ecologic environment. However, the increasingly serious air pollution, water pollution and soil pollution produced negative external effects on the sustainable development. (Please see the comprehensive table of mining activities and major environment issues)
The ecological environment has also become aggravated along with the development of economy. For example, the regional groundwater in Shanxi drops dozens of meter even over one hundred meters because of coal over exploitation, destroying the balanced system of overall surface water and underground, thus causes the depletion of water source and the river closure, where 280,000 people in 18 counties were difficult to get drinking water and 4,500,000 acres paddy fields turn into arid land[1]. Because of the sulfur dioxide pollution, the acid rain area in our country has occupied $30 \%$ of our country's land, which was mainly distributed in the south of Yangtze River and the east of the Qinghai-Tibet Plateau. There was a phenomenon that "ten rains, nine acid rains included" in Guangzhou in 2009, and urban district, where $96 \%$ precipitation assumes to be acidity, of which $77 \%$ precipitation is strong acid rains whose $\mathrm{PH}$ value is smaller than 4.5 [2].

TABLE I. THE COMREHENSIVE TABLE OF MINING ACTIVITIES AND MAJOR ENVIRONMENT ISSUES[3]

\begin{tabular}{|c|c|c|}
\hline $\begin{array}{c}\text { Environmental } \\
\text { Factors }\end{array}$ & $\begin{array}{c}\text { mining activities } \\
\text { related to } \\
\text { environment }\end{array}$ & $\begin{array}{c}\text { The major environmental } \\
\text { problem caused }\end{array}$ \\
\hline $\begin{array}{c}\text { Atmospheric } \\
\text { Circumstance }\end{array}$ & $\begin{array}{c}\text { The emission of waste } \\
\text { gas, dust and dross }\end{array}$ & Air pollution \\
\hline $\begin{array}{c}\text { Ground } \\
\text { the excavation of } \\
\text { ground and slope } \\
\text { groundwater } \\
\text { lowering, the } \\
\text { emission of effluent, } \\
\text { dross and surplus } \\
\text { mine }\end{array}$ & $\begin{array}{c}\text { Collapse of exploited area, } \\
\text { (mountain crack) collapse } \\
\text { landslide, mud-rock flow, } \\
\text { soil erosion, desertification, } \\
\text { the karst collapse, land } \\
\text { occupation, contamination, } \\
\text { mine-quake, tailing dam } \\
\text { break }\end{array}$ \\
$\begin{array}{c}\text { Water } \\
\text { Environment }\end{array}$ & $\begin{array}{c}\text { Groundwater } \\
\text { lowering, the } \\
\text { emission of effluent, } \\
\text { dross and tailings }\end{array}$ & $\begin{array}{c}\text { water imbalance, seawater } \\
\text { invasion and pollution }\end{array}$ \\
\hline
\end{tabular}

III. THE BASIC REASON OF ECOLOGIC ENVIRONMENT WORSENING IN MINGING AREA

The issues of heavy damage on the ecologic environment arouse many scholars' interests. They have composed many papers to deeply search the reason which causes the worsen mine environment, such as improper management, out-dated exploiting technology, the weak basis of economic, the insufficient legal supervisory system of mining environment. Although the above arguments have indicated the basic causes of mine pollution, they still could 
not find the origin source to explain why the mine enterprises and the related management system plunder the non-renewable resource continually and worsen the human living environment. To get the root of a matter, the basic reason lies in the wickedness of humanity ----egoism.

Humanity is the attribute which all the people have generally, just as Xun Zi said: "any person has nature, no matter gentleman or villain". [4]In china, the greatest dispute on the humanity issue is the kindness or viciousness of humanity. It is always the premise supposition and fundamental staring point of law and other disciplines research. The kindness in humanity as an ethical principle, also the ethic behavior of all conforms to the ultimate moral standard, is the behavior that promotes the benefit of the society and each person, is the behavior of benefiting society and individual, namely benefiting others and itself. However, viciousness is the act which harms itself and others, and the behavior which violates the ultimate moral standard. Egoism, which means viciousness differs altruism, which means kindness.

Pure egoism is the precisely essential manifestation of the individualism. The individualism advocates that egoism is a pure behavior which promotes the self-benefit through the self-choice, a way of absolutely not depending upon the society and other people. Otherwise, he will have no alternative but to lose freedom and allow the manipulation of society and other people. Then he will be an individual who is faceless, egocentric and primordial chose by them. From the perspective of biological gene, the purpose of complete egoism is the attribute of gene without doubt. If one's gene does not benefit oneself but others and remise other genes the chance of survival, he will be impossible to survive remises. The selfish gene is also the reason that the selfish motion occurs in life movement on various level, that is "the gene is the basis unit of egoism"[5]. However, the alienated modern individualism succeeds the essential meaning of ancient individualism: not only the society, the collective and other people do not have the supreme value to oneself, but also the advantage is light, harm is heavy, and what the value remains is the negative only. To the egoists, maintaining the self-benefit which is the only origin and goal of morality, is the ultimate standard to weigh good and evil. They think the self-value is supreme.

\section{THE BEHAVIOR AND PERNICIOUSNESS OF EGOISM OF MINE ENTERPRISES}

\section{A. The Egoism Behavior of Mine Enterprises}

The scarcity of human resources and the private ownership of property lead person's behavior to display selfish in nature. With the market economy's development, human's egoism coverers and corrodes altruism further. The enterprise makes itself as slaves of interests while pursuing the maximum profit. Driven by economic interests, mining enterprises resort to all means to reduce production costs. In order to save the cost of exploration and mining, mining enterprises do not develop specific investigation reports. To save costs, enterprises continue to use old, outdated equipment and technology, regardless of its geological resources of high energy extraction and waste. To save costs, enterprises adopt various means to simplify or even idle equipment and technology, despite the mining emissions and indiscriminate disposal of waste gas, water and remains.

\section{B. Perniciousness of Egoism of Mine Enterprises}

Adam Smith once had provided the theory which supported pure egoism, thinking the only responsibility of enterprise was to make money for the shareholder, besides, there was no other responsibilities needed to be considered, because when the enterprise sold product and made money, the invisible hand of the market would automatically adjust the social needs and balance the interests of the community. However, compensation for equal value equality and mutual benefit is the basic principles of commodity economy society where exchanges and the division of labor co-exist. In the field of large-scale social production, the basic features of modern economic life is to meet production for others and satisfy oneself by others, On the one hand, people are engaged in social production to create products and commodities, not to meet their own needs, but to the needs of others; On the other hand, people meet their needs of production and living mainly through the labor of others, rather than their own fruits of labor.

The ethical basis of such altruism makes the enterprise as a "social man" who achieves his self-interests only by altruism. A special self-interest people will tend to alienate from others and be self-destruction. Who only satisfies himself and detrimental to his people do not understand competition, and can not survive in the competition. Mining companies in the process of resource development and utilization win the profits at the expense of the environment, whose bearers of this huge cost are not mining enterprises, but the entire community. The pursuit of immediate short-term interests leads to in return long-term interests of the losses and serious damage to the environment, which is no good for long-term development of enterprises.

\section{V.The Legal Regulation of The Pure SELF-SERVING BEHAVIOR OF MINE ENTERPRISES}

The selfish nature of humanity and altruism, just as the coin has two sides, co-exist mutually. The history of human development is the process of two different human natures intertwining, conflicting and adapting each other. When mining enterprises seek profits in a improper way and do a great danger to human existing environment, how to regulate the conduct of mining enterprises' absolute egoism, how to guide them in the same time to consider the interests of others and society as a whole, and how to reach the aim of benefiting himself not harming others is the minimum requirements of the enterprise environment legal system. However, there are many shortcomings in the existing system of environmental legislation, for example, since China "Environmental Protection Law" has enacted since the planned economy time, it couldn't match with requirement of market mechanisms and society's 
sustainable development, which led to the problems of overlapping or gaping of environmental management and institutional arrangements, and imperfect environmental legislative system, it caused enterprises lacking of effective corporate social responsibility. Because "Environmental Protection Law", "Mineral Resources Law", "Water Law" and other environmental protection regulations on mines regulate too scattered and broad, the local administrative organs at all levels from the perspective of their own interests formulate their own administrative regulations and local laws and regulations, resulting the lack of effective coordination and convergence between different rank legal system, administrative regulations, and lack of effective implementation of supervision and punishment on mine corporations' polluted emissions. In order to further control the environment responsibility of the mining enterprises' egoism and strengthen the sustainable development idea, our nation should strengthen the legal control of mining enterprises as following aspects:

A. Inside the Mining Enterprise: Fully Introducing Environmental Director

Social responsibility mechanism was established in China Company Law of 2006 version. Although it enhanced protection of workers and creditors benefits through the adoption of improved governance structure, the mechanisms involved in commitment to environmental responsibility is very weak. Even if the independent directors system in listed companies can play a supervisory role, but its function is still very limited because of director's personal qualities, expertise and other factors. Thus, we can learn from foreign experience, introducing the Environmental Directors to environmental legislation. Environmental Protection Directors, include not only national environmental authorities, representatives selected by environmental NGO, but also the resident representatives of mining areas. Mining companies should ensure the supervisory right of the Environmental Directors to reach the fulfillment of corporate social responsibility.

B. On the Basis of Legal System, Establish a Sound Legal System of Ecological Monitoring System for Mines

1) Set "Pollution Control Regulation" as one of the fundamental laws

The "Environmental Protection Law" which enacted in 1989 should work as the basic law of environmental protection, regulating the basic principles, orientation, policies and environmental protection system, while the concrete implementations of each part should be stipulated by the single laws and administrative regulations which are under the ranks of the basic law. However, the "Environmental Protection Law" promulgated does not meet the actual existence of the legislative requirements, causing the potency conflict between the single item with itself. It also lacks of overall control and adjustments on our environmental protection on its content.

In order to comply with the recycling economy to needs of the sustainable development and the green ecological environment, the old "Environmental Protection Law" must be made a corresponding modification, such as the objectives, principles and environmental policy of environmental protection so as to establish a basic system and method; At the same time, the rights and obligations of state, local administration, citizen and society groups be cleared as well as the harmonious relations between the environmental protection with other socio-economic development and the relationship between environmental protection law with other laws in application be stipulated and confirmed. So under the clear command of the state basic law of environmental protection, including management of all aspects of environmental protection laws and regulations, can it launch and develop orderly.

2) Establish a sound environmental permit system

Mine environmental permit system refers to a set of management measures that before mining exploration and exploitation activities which is harmful or potentially harmful to environment, the enterprises must hand in the application to the environmental management authorities, and only after be examined and permitted is allowed can they carry on this activity. [6]At present, in the process of examining mineral resource exploration and development, the concerned authorities are only responsible for the qualifications of prospecting mining enterprises. They do not request the mine enterprises to report their pollution discharge quantity in exploration and not issue the permits according to the size of the pollution discharge quantity. Mine environmental permit system is conducive to prior investigation of pollution and damage caused by exploration activity, and take control of possible destruction to the ecological environment from the source.

Through registration of mime discharge report, the concerned authorities can not approve the activity which does not meet the environmental protection requirements. They can also regulate restrictive conditions and requirements according to the change and need of objective circumstances, such as determining the total pollutant index by the capacity of local ecological environment, and determining the emissions, issuing permit by the feasibility analysis of technology and economy, to strengthen the supervision and management of mining activities.

3) Establish the ecological compensation system in the process of exploration of mineral resources

Long-term extensive mode of exploitation of mineral resource and the self-interest behavior which pursue the high profit cause deterioration of ecological environment around the mining area. Learning from the European and American countries' successful management experience, ecological compensation system should be established to effectively control the source of environmental pollution. Ecological compensation system emphasizes the pursuit of economic development adhere to the principles of environmental priorities. It focuses on a comprehensive and detailed supervision over possible damage to environment at each stage of exploration, stresses the institutionalization and reutilization of management, meanwhile, paying great attention to the coordination and integration between systems and the application of various environmental management techniques and methods. Only vigorously promote the mine ecological compensation system can fundamentally solve the funds of environmental 
improvement and effectively control the absolute self-serving behavior of enterprises'.

4) Establish a sound margin system of mine geological environment recovery

Although the "Environmental Protection Law", "Mineral Resources Law", "Land Management Law" and the "Coal Law", "Water Law", etc. have provisions on liability for environmental damage, these provisions are overly form, and there is no specific responsibility. Such as, it is not clear that who should bear the responsibility for mine geological environmental governess, how to define the relations of each part's right, responsibilities and interests and how to supervise effectively. Therefore, we must step up to establish a sound margin system of mine geological environment recovery, and guarantee there are effective laws to abide. While conscientiously implement the "Mineral Resources Law", "Environmental Protection Law" and other laws, regulations and related policies, according to the principle of "who destroy, who govern", take measures of governess for mine geological environment for whom has responsibility, the government should introduce appropriate policies to encourage the management of geological environment, and in accordance with the principle of "who govern, who benefits" to give enterprises favorable policy that engage in governess of mine geological environment. The government should also conscientiously implement the "Mineral Resources Law" and related regulations of resources management; strictly examine new mines in accordance with the law, and uniformly executing the margin system of mine geological environment recovery. Enterprises are required to pay deposit according to the size of mining area and the years of mining, to formulate mine environmental management program and to sign signed letters of responsibility for mine ecological environment governess, so as to control the occupation and destruction of mining land from the source, which facilitate the governess of geological environment after the enterprises stop mining.

\section{CONCLUSION}

The establishment and improvement of legal system above-mentioned will fully strengthen the guidance of the mining production and operation from the perspective of macro adjustment to market regulations; enterprises are urged to obey the laws and regulations in each step. When in the pursuit of profit, they can consciously take social responsibility of resource utility and reduction of pollution emissions for the implementation of cleaner production. This is not only the intrinsic request of socialist market economy, but also is the inevitably choice of the mining enterprise's survival and development in environmentalist era.

\section{ACKNOWLEDGMENT}

The paper was sponsored by 2013Jiangxi Colleges and Universities' Humanity and Social Science projects-“" Legal System Researches on Ecological Environment Protection System on Mineral Resources Exploitation" (Projects NO: FX1301) and 2013 Key Social Science Planned Projects of Fuzhou City, Jiangxi Province

\section{REFERENCES}

[1] Haiming Wang. Humanity, Commercial Press, 2005.

[2] Milton Friedman. The Social Responsibility of Business is to Increase Its Profits. In Tom L.

[3] [UK]Adam Smith. Wealth of Nations. Translated by RIsong Tang etc, Commercial Press, 1972

[4] Xunzi •Zhengming

[5] Zhongmei Lu .Introduction to Environmental Law, Peking University Press, 2008 